$$
\begin{aligned}
& \text { بروسى عوامل موثر بر یوشش كياهى در رويشغاههاى آبى و مرطوب پاركى ملى بوجاق، كياشهر، } \\
& \text { استان كيلان } \\
& \text { محدثه مقصودى'، شهر يار سعيدى مهرورز } \\
& \text { دريافت: . } \\
& \text { 'يُزوهشكدة محيط زيست جهاد دانشخاهى، رشت }
\end{aligned}
$$

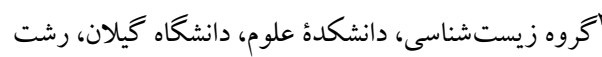

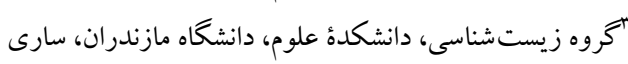

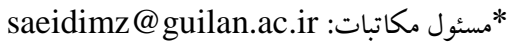

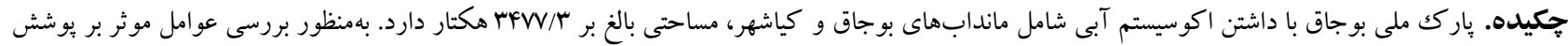

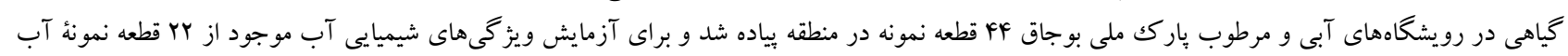

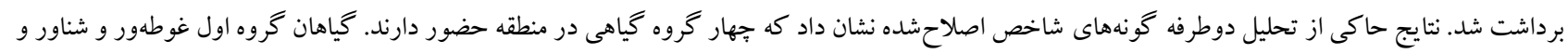

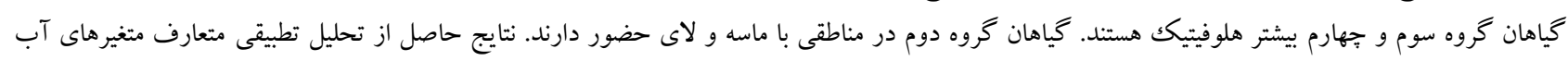

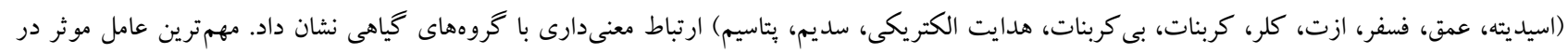

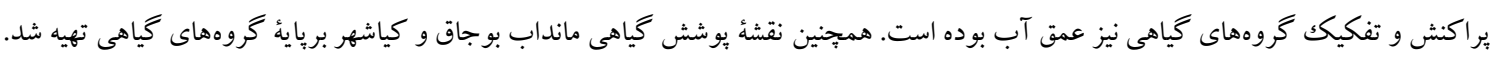

$$
\begin{aligned}
& \text { وازههاى كليدى. مانداب، عوامل محيطى، گروههاى گياهى، نقشه يوشش گياهى، شمال ايران }
\end{aligned}
$$

\title{
The study of factors affecting the vegetation in aquatic and wet habitats of Boujagh National Park, Kiashahr, Guilan Province, Iran
}

\author{
Mohaddeseh Maghsoudi ${ }^{1}$, Shahryar Saeidi Mehrvarz ${ }^{2} *$, Alireza Naqinezhad ${ }^{3}$ and Mokarram Ravanbakhsh ${ }^{1}$
}

${ }^{1}$ Academi Center for Eduction, Cultural Research (ACECR), Environmental Research Institute, Rasht, Iran

${ }^{2}$ Department of Biology, Faculty of Science, University of Guilan, Rasht, Iran

${ }^{3}$ Department of Biology, Faculty of Science, University of Mazandaran, Sari, Iran

*Correspondent author: saeidimz@guilan.ac.ir

\begin{abstract}
Boujagh National Park, with water ecosystems including Boujagh and Kiashahr wetlands, has an area of approximately 3477.3 hectares. In order to study factors affecting the vegetation in aquatic and wet habitats, 44 releves were implemented in the region. To test the chemical properties of the available water, samples were collected from 22 releves. The results of a two-way species indicator analysis of the modified TWINSPAN suggested that four groups of plants were present in the region. The first group being floating, immersed and submerged and the third and fourth groups being mostly helophytic. The second group of plants grows in areas with sand and mud. The results of comparative DCA analysis of water factors ( $\mathrm{PH}$, Depth, $\mathrm{P}, \mathrm{N}, \mathrm{Cl}, \mathrm{CO}_{3}, \mathrm{Hco}_{3}, \mathrm{EC}, \mathrm{Na}, \mathrm{K}$ ) showed a significant correlation between the factors and plant groups and the most important factors influencing the distribution and separation of plants was found to be water depth. In addition, Boujagh and Kiashahr wetlands vegetation map, based on the plant groups, was also prepared.
\end{abstract}

Keywords. wetland, environmental factors, plant groups, vegetation map, Iran 
درياى خزر و محل زمستان گذرانى گونههاى مختلف برنده به -

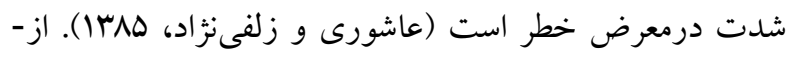

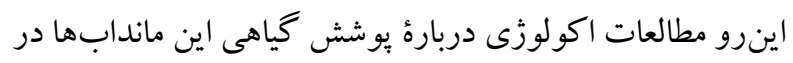

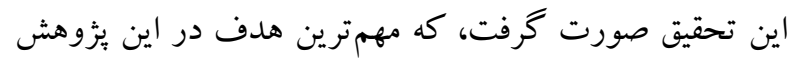

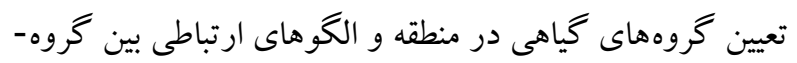

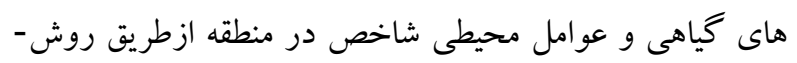
هاى رستهبندى و طبقهبندى و تحليلهاى آمارى و تهيه نقشه يوش كياهى است.

\section{مواد و روشها}

منطقةٌ تحت مطالعه

هار كك ملى بوجاق در استان گَيلان، شهرستان آستانه اشرفيه و در شهر كياشهر قرار گرفته است. مساحت آن طبق آمار اداره كل

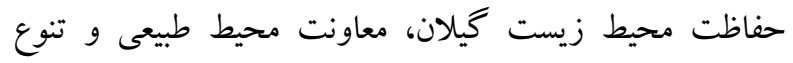

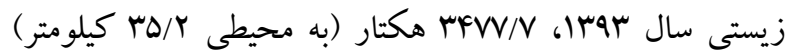

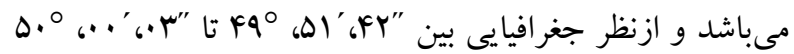
طول شرقى و "

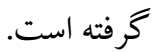

يار كك ملى بوجاق اولين پار كك ملى خشكى -دريايى در شمال ايران است كه مجموعة لاكون يا مرداب كياشهر و دهانه بأن

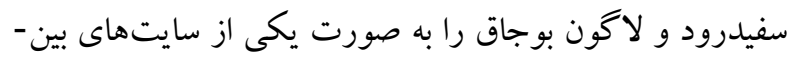

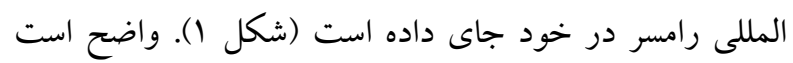

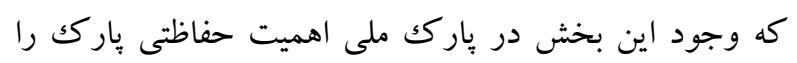
جند برابر مى كند. طبق سازمان زمينشناسى واكتشافات معدنى كشور سال سوجسا،

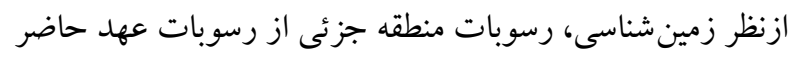

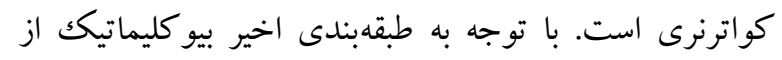

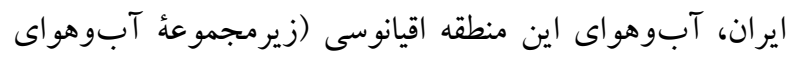

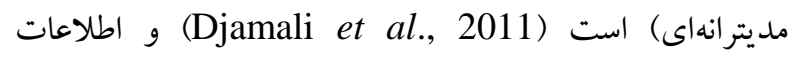

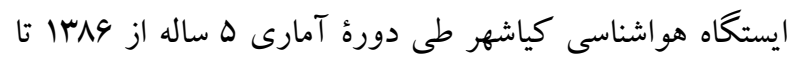

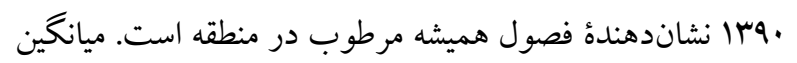

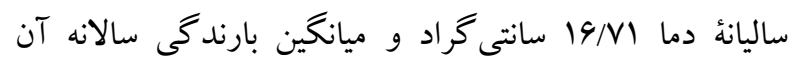

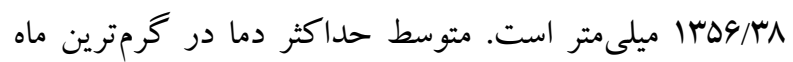

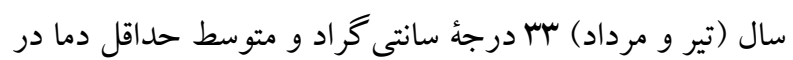

شناخت اكوسيستمها و رويشخاهها بههمراه حفظ و نخهدارى

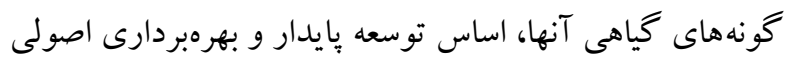

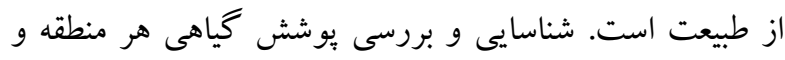
ارتباط بين اجتماعات گياهى و عوامل محيطى از بهترين راهنماها قضاوت در مورد وضعيت بومشناختى آن منطقه و ارزيابى آنى وضعيت كنونى و بيشبينى وضعيت آينده منطقه است، بنابراين

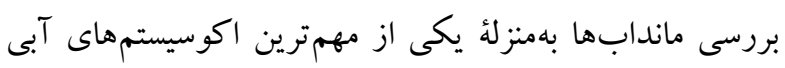

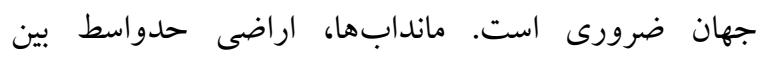

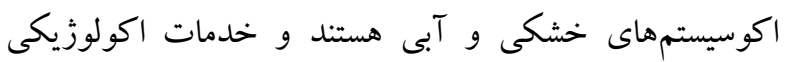
ارزشمندى نظير حفظ تنوع زيستى، حفظ كيفيت آب،

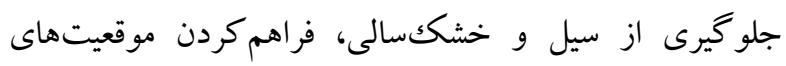

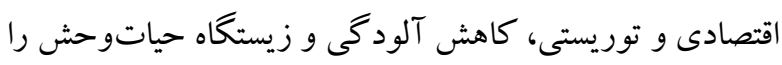

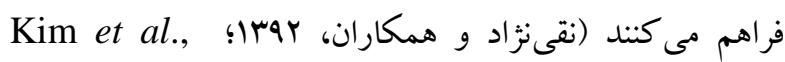
.2011) شناخت گروههاى گياهى هر منطقه در شناخت اعمال اكوسيستم و تكامل بيولوزيكى آن منطقه نقش اساسى دارد ) Edward,

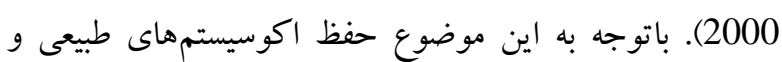

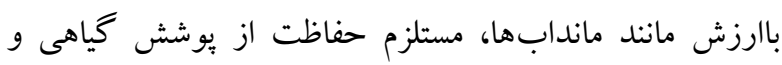
شناخت عوامل محيطى مؤثر بر آنها است (Sabeti, 1969).

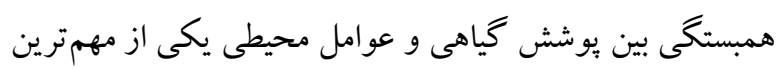
مسائل تأثير گذار در شكل گيرى ساختار جوامع گياهى و و

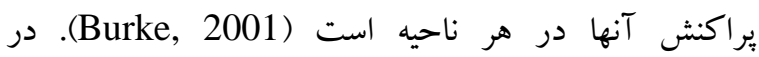
اكوسيستمهاى آبى، عمق آب و عناصر غذايى در دريه تغييرات يوشش كياهى نقش كليدى بازى مى كنند.

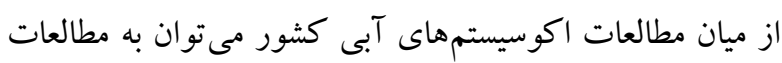

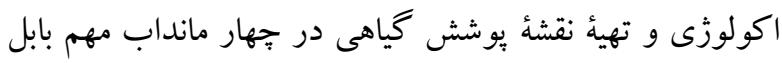

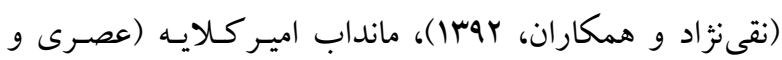

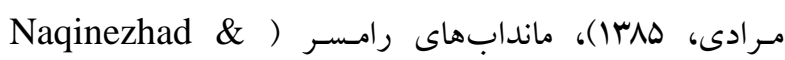
Khoshravan, 2010 )، مانداب انزلى (جليلى و همكاران،

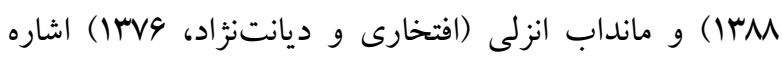
كرد. همجنين بررسى فلور و تهيئ نقشهُ فيزيونومى - فلورستيكى دئي

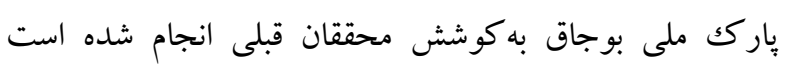

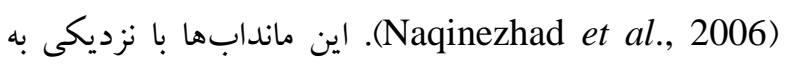


r. اكولوزى و اندازه كيرى فاكتورهاى محيطى، آب نيز از عمق

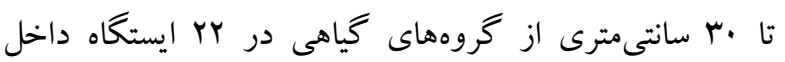

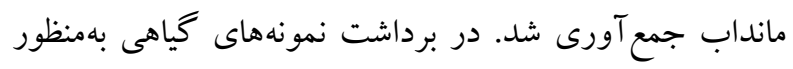

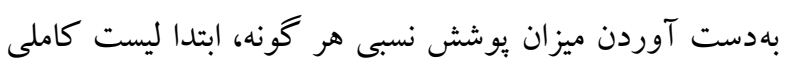

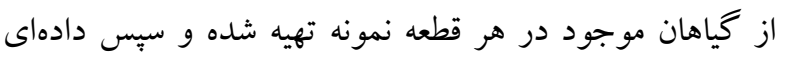

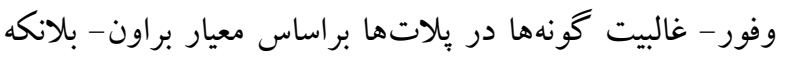

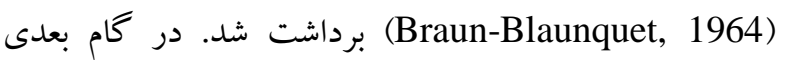

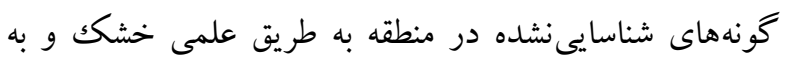

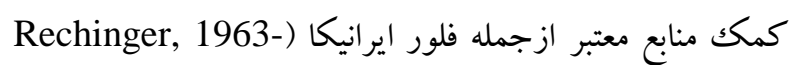

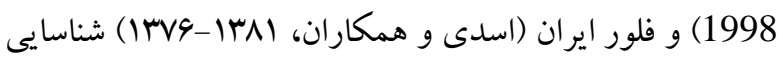

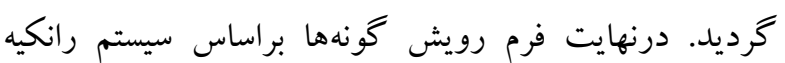
(Raunkiaer, 1934)

سردترين (دى و بهمن) ماه سال \&/ • درجة سانتى گراد بوده است .(Naqinezhad et al., 2006)

\section{جمع آورى اطلاعات}

باتوجه به اطلاعات اداره كل حفاظت محيط زيست گيلان،

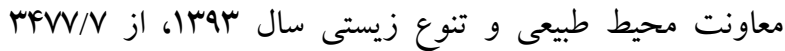

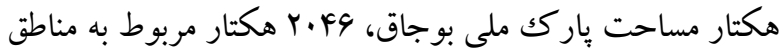

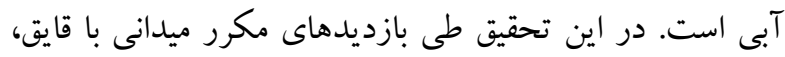
دستخاه GPS و نقشهاى تويو گرافى و تصاوير ماهوارهاى حدود منطقه تعيين شد و محل قطعه نمونهها بهصورت

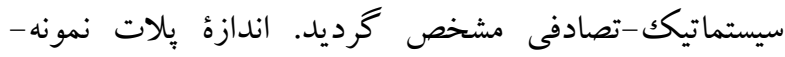
بردارى با روش سطح حداقل نمونهبردارى و با توجه به ماهيت

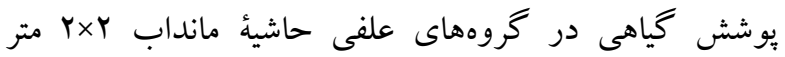

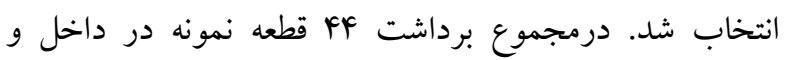

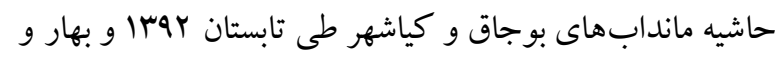

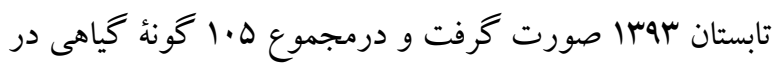

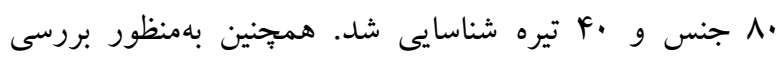
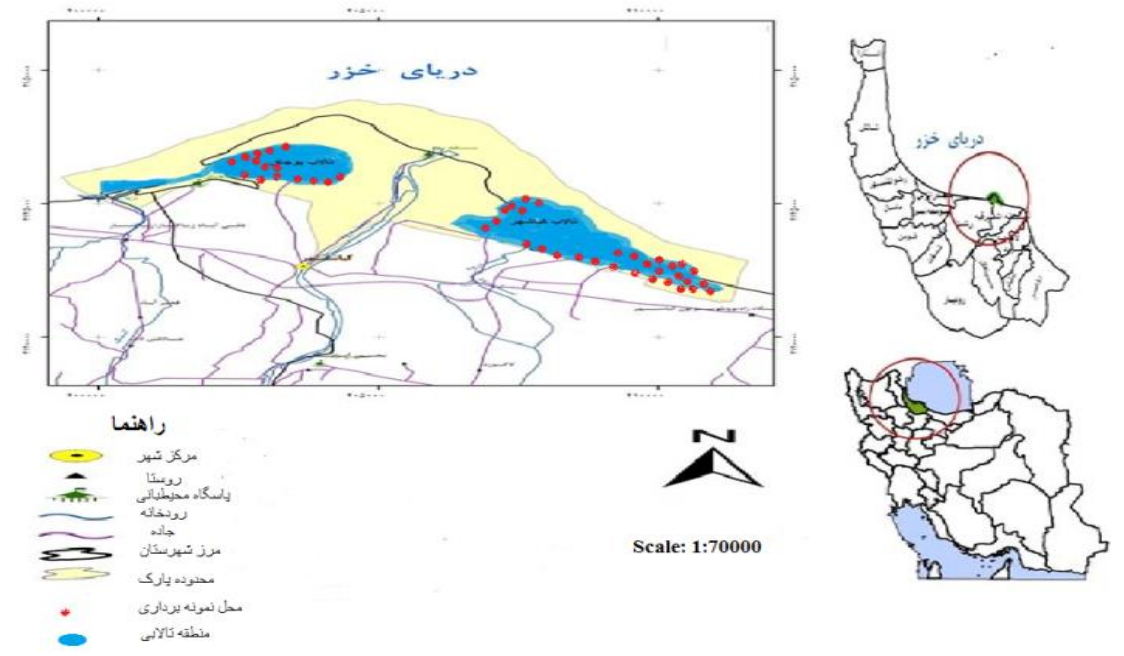

شكل ا-موقعيت مانداب بوجاق و كياشهر نسبت به رود خانه سبيدرود؛ محل نمونه بردارى كه با نقطة قرمز مشخص كرديده است.

Fig. 1. Boujagh and Kiashahr wetland position to the Sepidrud River; the sampled locations have been specified with red dots.

كلر ايد از روش ولومترى، سديم و پيتاسيم به روش فليم فتومتر و

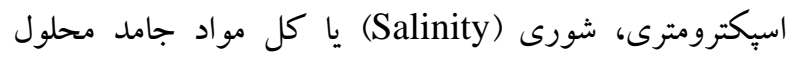

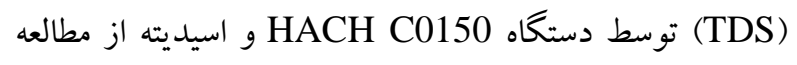
Velthorst
متغيرهاى آبى شامل اسيديته بهوسيلة دستكاه CP-411، هدايت-

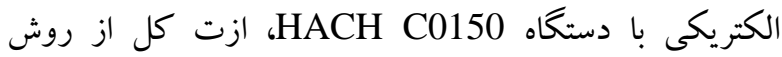
ميكرو كجدال، فسفر كل ازطريق آشكارسازى يونى، كربنات و بى كربنات از روش تيتراسيون اسيد سولفوريك و متيل اورانز، 
داراى جريان كند است كه بهطور كامل شامل گياهان هيدروفيت

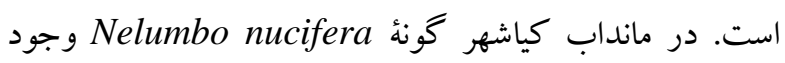

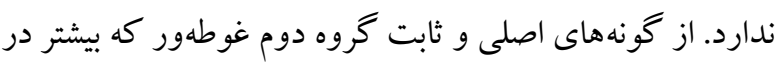
مناطق مركزى و با عمق زياد حضور دارند مىتوان به موارد زير

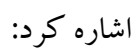

Ceratophyllum demersum, Myriophyllum spicatum L., Nelumbo nucifera, Potamogeton crispus L., Potamogeton pectinatus L., Potamogeton pusillus L., Zannichellia palustris $\mathrm{L}$.

در گروه دوم (Rubus sanctus و Juncus acutus L.) (schreb.

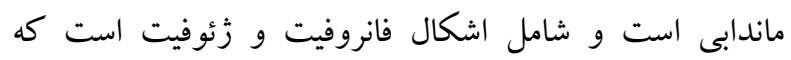

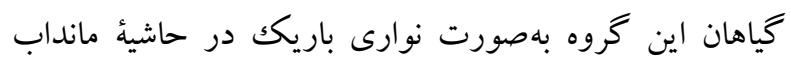
كياشهر (قسمتهاى شرقى و غربى) و مانداب بوجاق (قسمتهاى شمالى و جنوبى) وجود دارد. Juncus acutus كونة

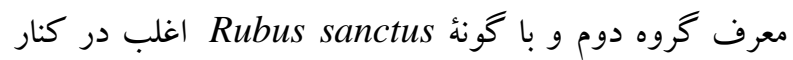
هم رويش دارند. Equisetum ramosimum Desf. Geranium molle L.و از ديخر گونههاى اين گروه هستند. گروه گياهى سوم (Mentha acuatica L.) australis (Cav.) Trin ex Steud.

(Cav.) Trin. ماندابها را در برمى گيرد. در اين گروه گتونه Phragmites australis باريك دور تادور مانداب بوجاق و كياشهر را اشغال نموده است. Mentha aquatica هاى مرطوب ماندابى خصوصاً در بخشهاى شرقى مانداب كياشهر و جنوبى مانداب بوجاق حضور دارد.

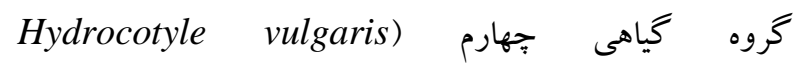
و و (Phragmites australis (Cav.) Trin ديده مىشود. از گونهُ معرف گروه جهارم كه در بين مناطق

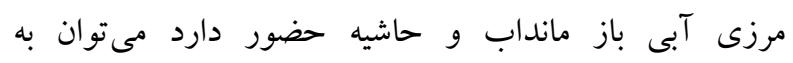
Hydrocotyle vulgaris كياشهر و در قسمتهاى شمال شرقى و شرقى آن (تحت عنوان

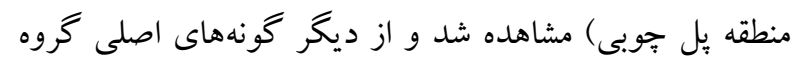
Fروه گياهى جهارم مىتوان Phragmites australis

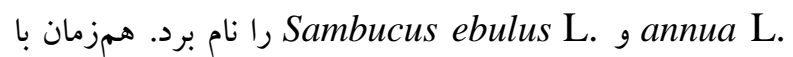
تعيين گروههاى گياهى با استفاده از طبقهبندى TWINSPAN،

\section{تهية نقشهُ يوشش كياهى}

در مطالعة حاضر نقشهٔ يوشش گياهى با نرمافزار

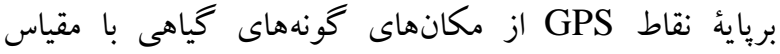

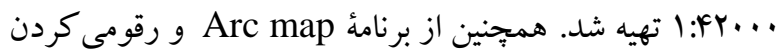
لايهاى (عوارض) استفاده شد، يعنى لايههاى ايجاد شده از

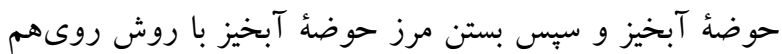
ردكردن خطوط در محل تلاقى انجام شد. پيساز ترسيم

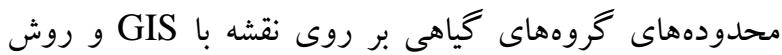

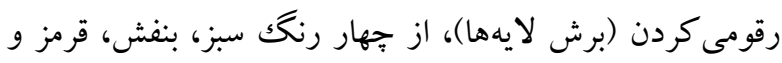

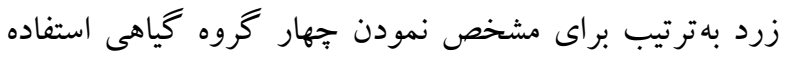

\section{تجزيه و تحليل دادهها}

بهنظور طبقهبندى يوشش و تعيين گروههاى گياهى، تكنيك ردهبندى و خوشهبندى Hill, ) Modified TWINSPAN JUICE درقالب نرمافزار (1979; Roleček et al., 2009

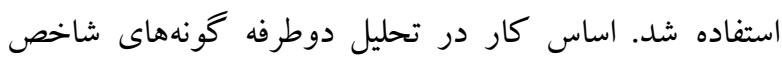
اصلاح شده بر مقايسه قطعات نمونه براساس وجود يا فقدان وجود گونه ها است (Braak \& Smilauer, 2002). بهنظور تعيين ارتباط گروههاى گياهى با عوامل محيطى از تحليل DCA انجام شده، مطالعه در قالب نرمافزار 4.5 استفاده شد (Lepš \& Šmilauer, 2002). همجِنين تحليل One Way ANOVA، بههمراه آزمونهاى تشخيص Post-hoc Tukey عوامل مختلف محيطى و اكولوزيكى استفاده شد.

\section{نتايج}

باتوجه به گروهبندى يوشش گياهى باستفاده از تكنيك رده

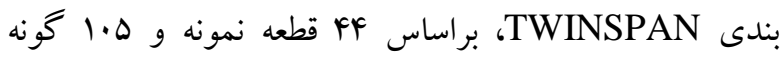
گياهى، جهار گروه اصلى يوشش گياهى در منطقه تشخيص

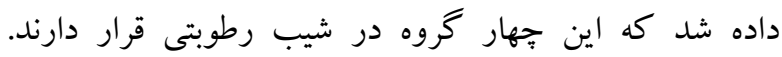

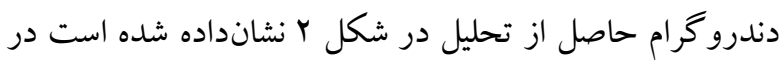

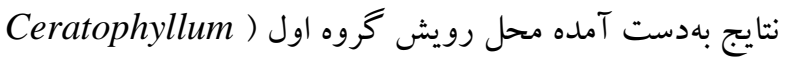
(Nelumbo nucifera Gaertn.و demersum L. مركزى مانداب بوجاق است و آب در اين قسمتها كمعمق و 
مىدهتد كه عمق آب در جداكردن بوششهاى مختلف گياهى

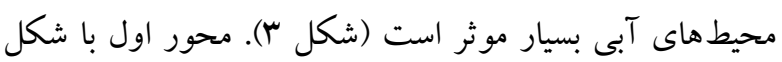

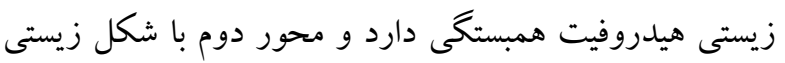

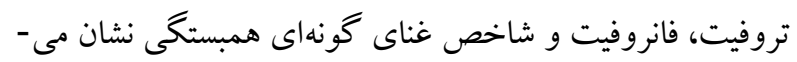

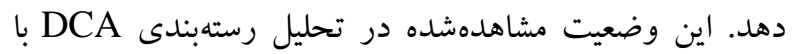

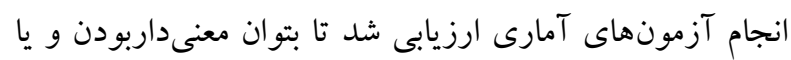

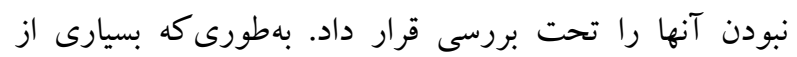

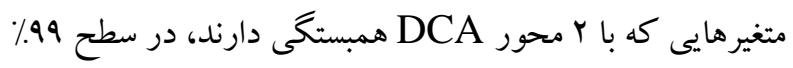

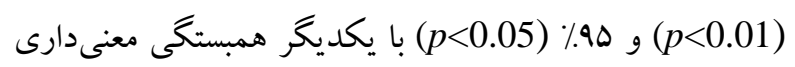

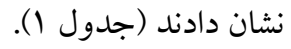

بهنظور نشاندادن گروههاى گياهى كه اين تحليل تعيين كرده

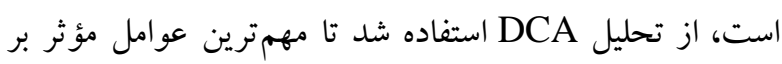

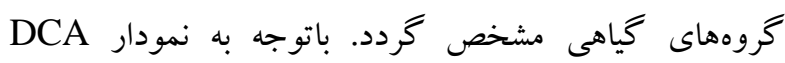

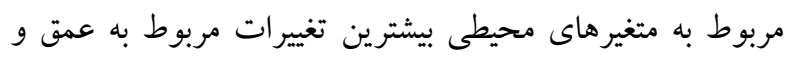

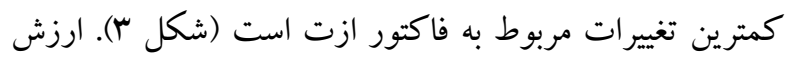
محورى براى دو محور اول تحليل DCA بهترتيب ای/· و هه/•

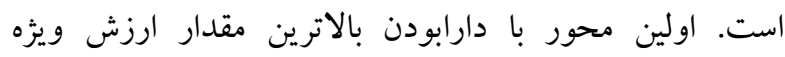

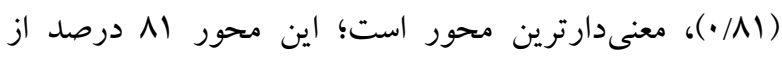
تغييرات را توجيه مى كند و بلندترين طول شيب در اين تحليل

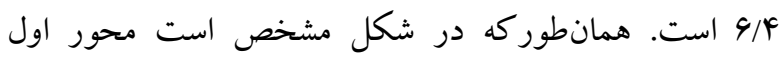

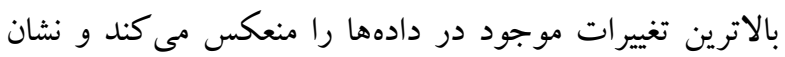

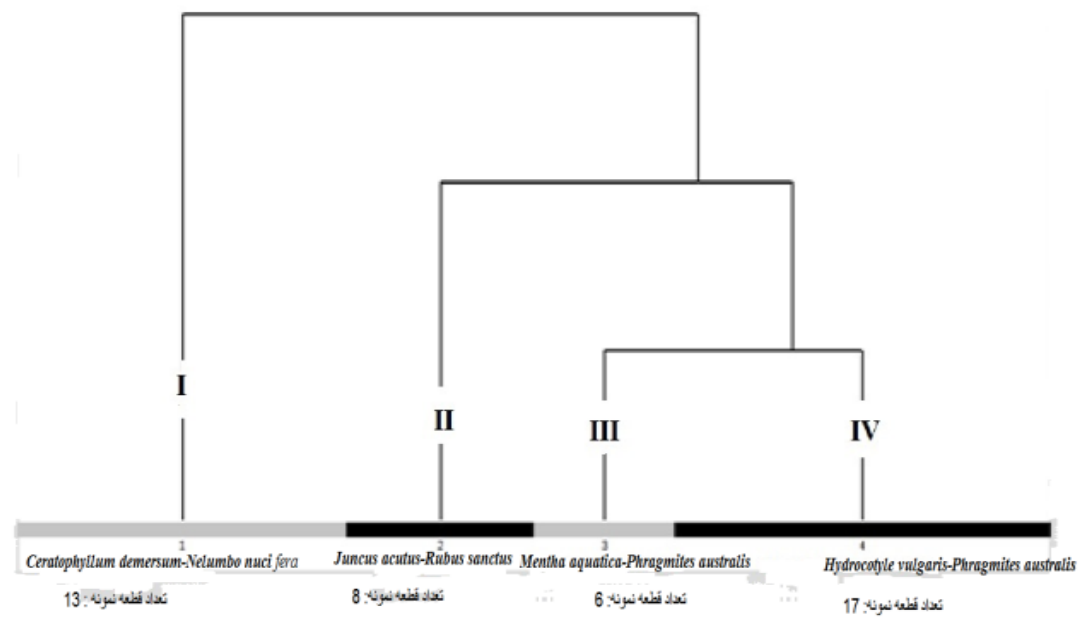

شكل r- دندو گر ام حاصل از ردهبندى دوطرفة گونهاى شاخص اصلاح شده با مشخص كردن جهار گروه يوشش گياهى.

Fig. 2. Dendrogram of the modified TWINSPAN classification accompanied with specification of the four vegetation groups.

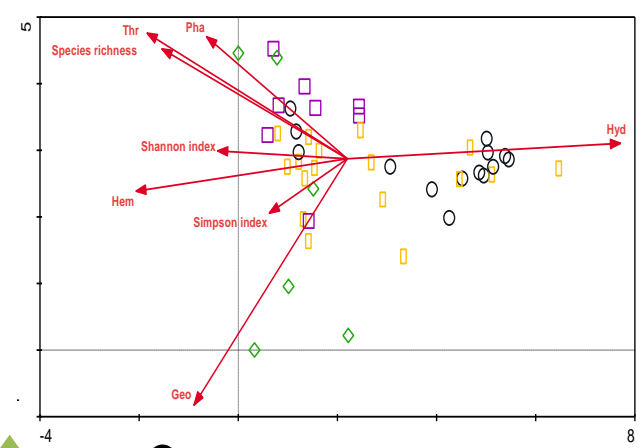

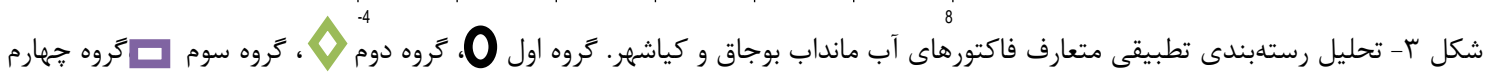

Fig. 3. DCA analysis of water factors in Boujagh and Kiashahr wetlands: first group $\mathbf{0}$, second group $\boldsymbol{\nabla}$, third group , fourth group 


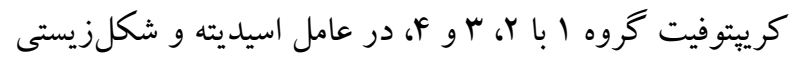

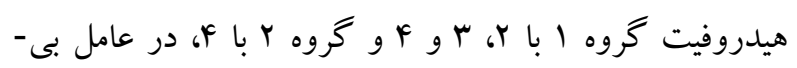

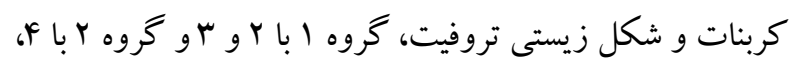

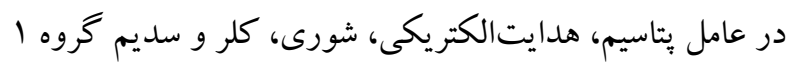

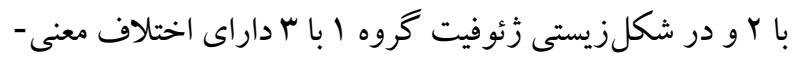
دارى هستند (جدول (1). عوامل هدايتالكتريكى، شورى،

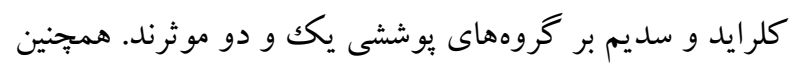

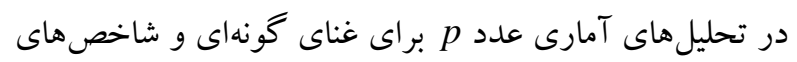

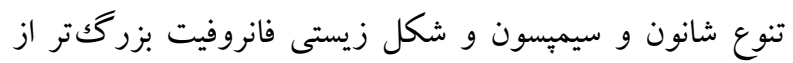
ه•• بوده است (جدول ()، كه نشاندهندة كمبودن و رو به كاهشبودن غناى گونهاى و تنوع زيستى در منطقه بهخصوص لهو

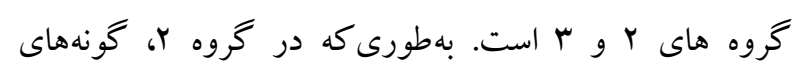
Juncus acutus Suncus acutus Rubus scantus كونه معرف گروه دوم در مناطقى كه خاكك داراى ماسه و لاى

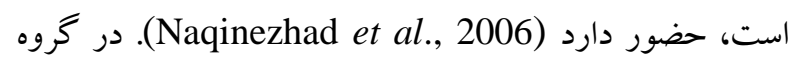
r، گونه . Phragmites australis (Cav.) Trin. غالب شده است كه بهصورت نوار باريك دور تا دور مانداب

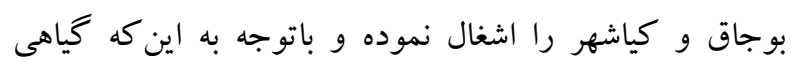

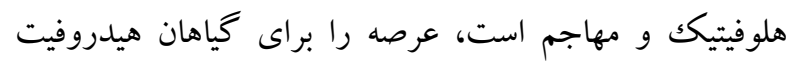

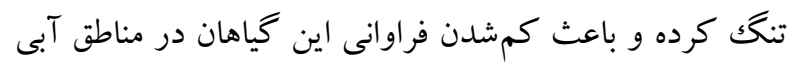

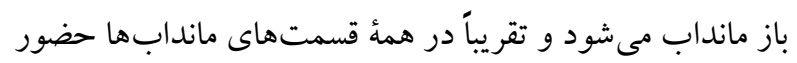
گسترده دارد (عصرى و افتخارى، الیشا؛ عصرى و مرادى،

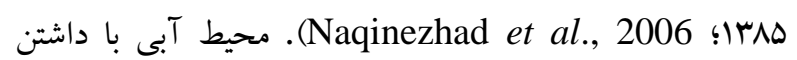
هيدورفيتها نسبت به حاشئ ماندابها از غناى كمترى برخوردار است و تنوع زيستى نيز در آن كاهش مىيابد. در حاشيه ماندابها نيز شكل زيستى تروفيت بيشرين حضور را دارد Naqinezhad et al., 2006) ديخر اشكال زيستى هم در محيطهاى حاشيهاى غالبترند به

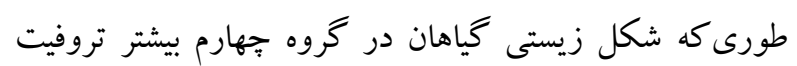

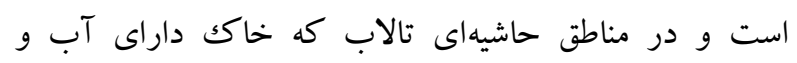
(Naqinezhad et al., رطوبت بالا است ديده مىشوند (2006. در اكوسيستم آبى بهدليل شرايط محيطى يكنواخت،

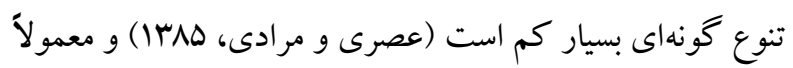

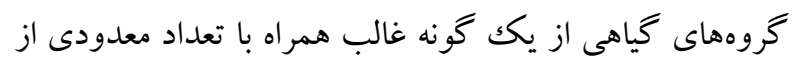

در محيط آبى، هرجه عمق بيشتر شود شكل زيستى هيدروفيت

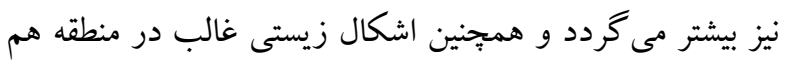

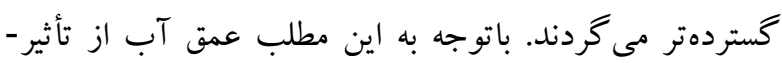

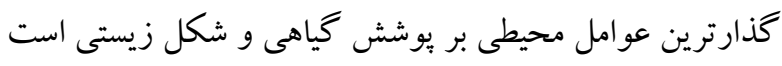

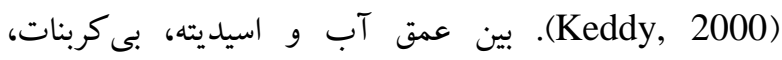

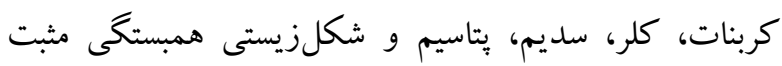

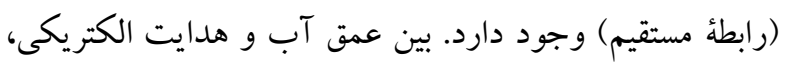

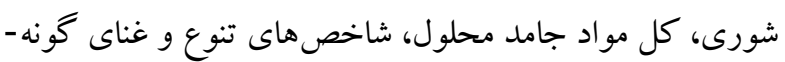
اى همبستخى منفى (رابطةُ معكوس) وجود دارد.

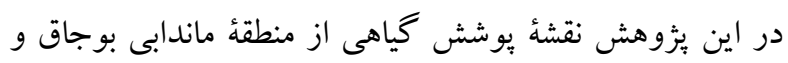

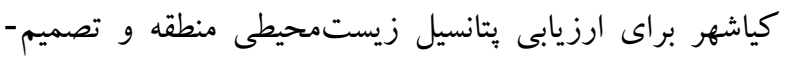

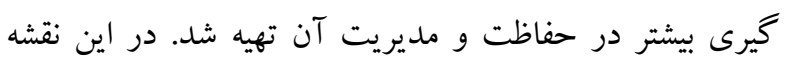

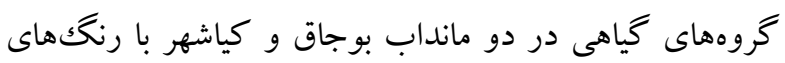

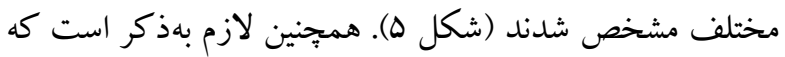

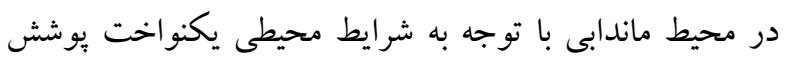
كياهى، نقشه ترسيم شد.

\section{بحث}

تجزيـه و تحليل هاى حاصل از طبقهبندى دوطرفه گونه-

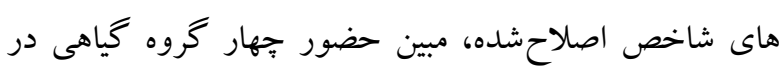

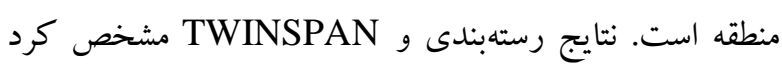
جهار گروه گياهى تعيين شده براساس ويز گیىهاى محيطى از هم

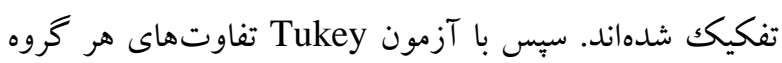
با گروههاى ديخر مشخص شد. بررسى تأثير عوامل فيزيكى و شيميايى آب بر خروههاى گياهى

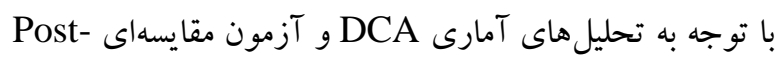
hoc Tukey

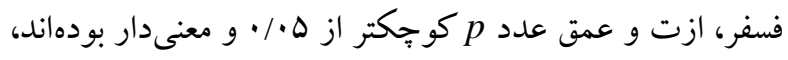

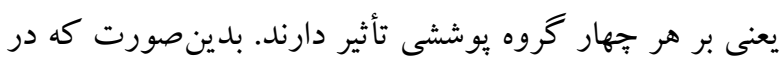

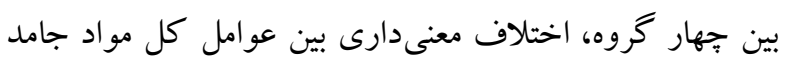

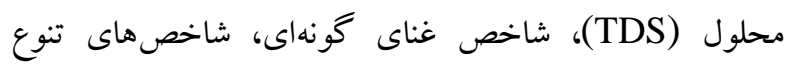

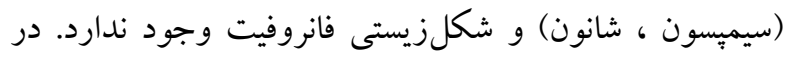

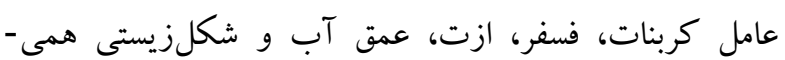


Zannichellia palustris, Potamogeton pectinatus , Myriophyllum spicatum.

گونههاى گياهى گروه اول اساساً در آبهايى با عمق متوسط،

مشاهده مى شوند (عصرى و مرادى، هيرا؛ Naqinezhad et (al., 2006 همجنين عمق آب فاكتورى برجسته در استقرار يوشش گياهى آبزى سيستمهاى آب شيرين در سراسر جهان

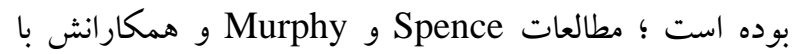

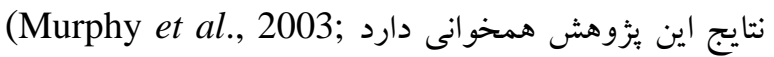
(Spence, 1967) تغييرات عمق آب كه گسترة آن بين صفر تا ... سانتىمتر و

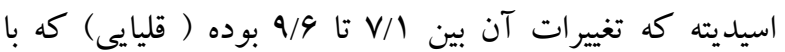

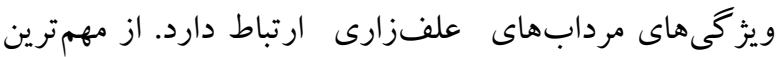

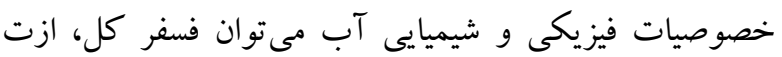

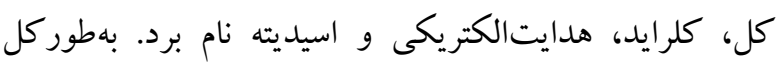

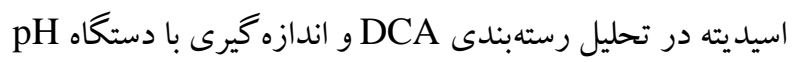

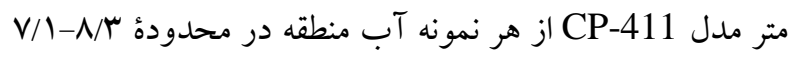

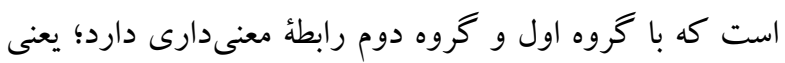

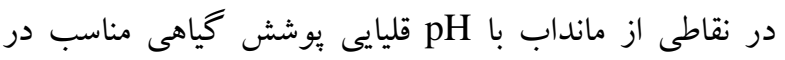

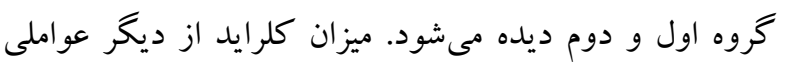
است كه در منطقه تحت مطالعه ميزان آن بين A/•-ا// ميلى

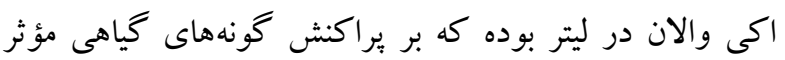

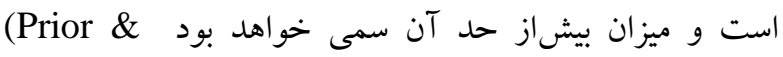

گونهاى گياهى تشكيل شده است، مانند گروه گياهى دوم Mentha و و سوم Rubus sanctus Juncus acutus .aquatica- Phragmites australis (Cav.) Trin. اين شرايط يكك گونه بهدليل سازشيذيرى زياد عرصهُ درخور توجهى را اشغال مى كنند.

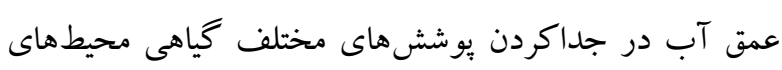
آبى بسيار موثر است (Tsuyuzaki et al., 1990) و اولين

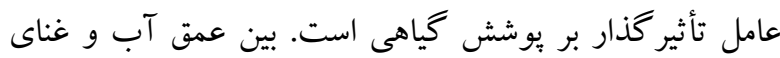

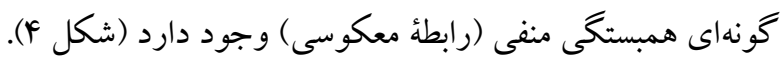
بهورى كه، محيط ماندابى با داشتن هيدورفيتها از غناى كمترى در مقايسه با محيط مرطوب برخوردار است و تنوع

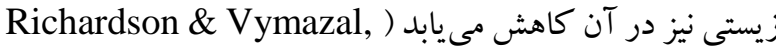
2001). در مناطق حاشيهاى كه عمق كمتر است، گونهاى

$$
\text { كياهى بر آمده از آب زير حضور دارند }
$$

Phragmites australis, Schoenoplectus litoralis Typha (Schrad.) Palla, Typha domingensis Pers., Sparganium neglectum Beeby g L. latifolia در مناطقى از مانداب كه عمق زياد مىشود گونههاى گياهى غوطهور و شناور مشاهده مى شوند. نظير:

Nelumbo nucifera, Ceratophyllum demersum, Chara spp., Azolla filiculoides Lam., Hydrilla verticillata (L. F.) Royle, Utricularia neglecta Lehm., Lemna minor L., Potamogeton perfoliatus L., Potamogeton crispus, Potamogeton pusillus,

.Berthouex, 1967)

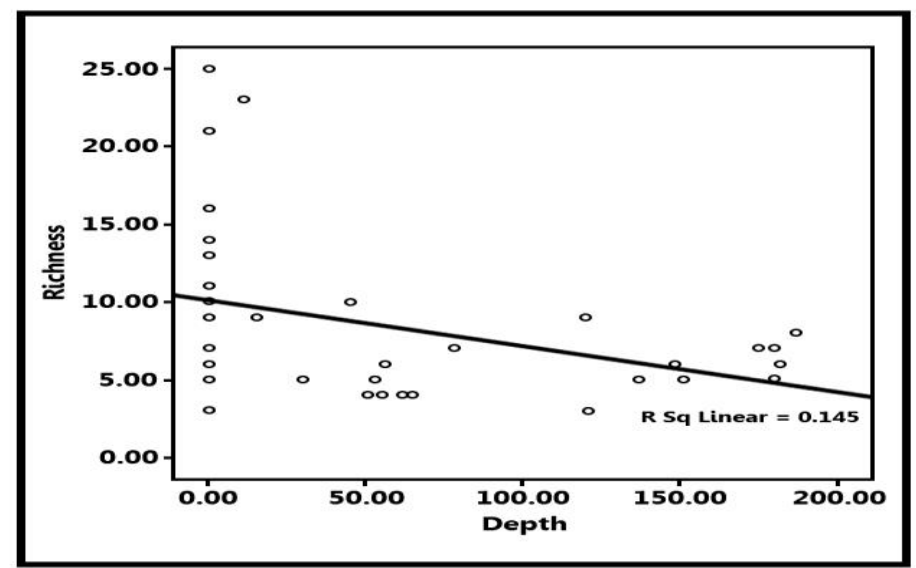

شكل \&- نمودار ارتباط بين عمق و غناى كونهاى.

Fig. 4. Diagram of the relationship between species richness and depth. 


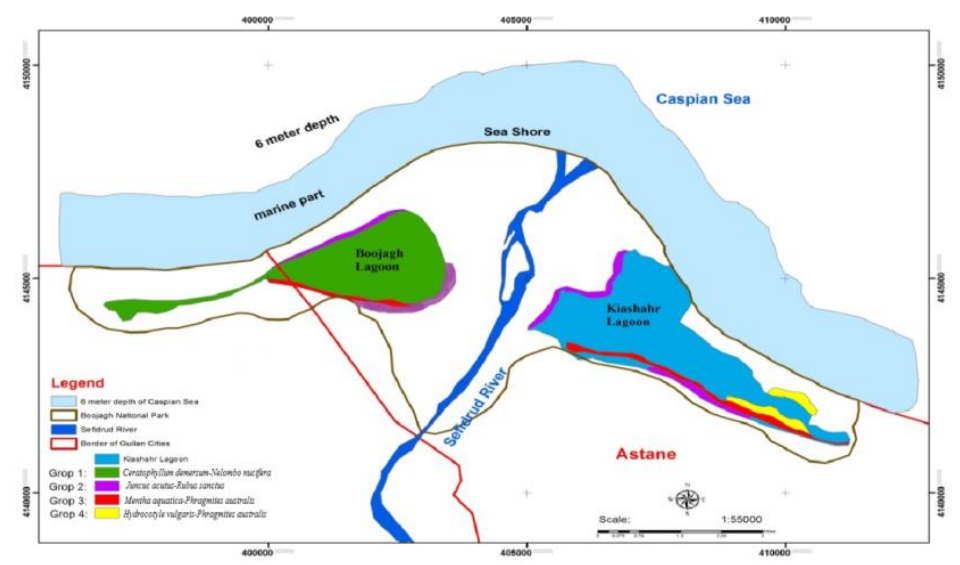

شكل ه- نقشأ يوشش كياهى مانداب بوجاق و كياشهر.

Fig. 5. Vegetation map of Boujagh and Kiashahr wetlands.

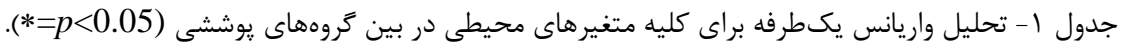

Table 1. One-way ANOVA analysis for all environmental variables among vegetation groups $(*=p<0.05)$.

\begin{tabular}{|c|c|c|c|}
\hline متغير هاى محيطى و اشكال زيستى & F مقدار F & مقدار P P & Post-hoc Tukey \\
\hline اسيديته & $11 / \mathrm{V} 1$. & $\cdot / \cdots$ & $1-2,1-3,1-4,2-4$ \\
\hline ازت & 9/449 &.$/ \cdots 1$ & $1-2,1-3,1-4$ \\
\hline فسفر & $\varepsilon / 4 \lambda$. &.$/ \cdot 1$ & $1-2,1-3,1-4$ \\
\hline عمق & $1 \cdot / 119$ & $\cdot / \cdots$ & $1-2,1-3,1-4$ \\
\hline شورى & T/QTY & .1 .4$. & $1-2$ \\
\hline همى كرييتوفيت & $\mathrm{V} / .9 \mathrm{~V}$ & $.1 . .1$ & $1-2,1-3,1-4$ \\
\hline رئوفيت & $r / V \Delta T$ & .1 .1 & $1-3$ \\
\hline فانروفيت & $\cdot / \Lambda \cdot V$ &.$/ 497$ & بدون اختلاف معنى دار \\
\hline تروفيت & N/199 & $\cdot / \cdots$ & $1-21-3,2-4$ \\
\hline هدايت الكتريكى & r/A99 & $.1 .4 \Lambda$ & $1-2$ \\
\hline كلرايد & $4 / .94$ & .1 .14 & $1-2$ \\
\hline هيدروفيت & ID/ATD & $.1 \cdots$ & $1-2,1-3,1-4,4-2$ \\
\hline بـ بـربنات & N/r99 & $\%$ & $1-2,1-3$ \\
\hline كربنات & $1 / 499$ & $\cdot / \cdots$ & $1-2,1-3,1-4$ \\
\hline شاخص شانون & $\cdot$ / IAG &.$/ 49 \mathrm{~V}$ & بدون اختلاف معنى دار \\
\hline קֶ: & r/gAt & $\cdot \cdots v$ & $1-2$ \\
\hline غناى كونهاى & T/THT & $\cdot 1 \cdot 11$ & بدون اختلاف معنى دار \\
\hline سديم & T/NGY & $.1 .4 \Lambda$ & $1-2$ \\
\hline شاخص سيمِّون & $\cdot / r \mid f$ & $\cdot / 119$ & بدون اختلاف معنى دار \\
\hline
\end{tabular}

اكولوزيكى داشته و همجنِن الكوهاى ساختار رويشى را تعيين

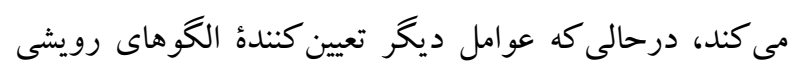

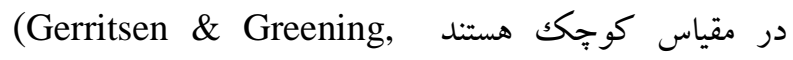

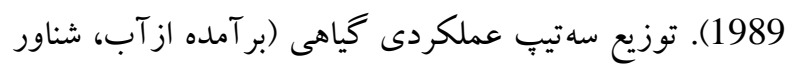

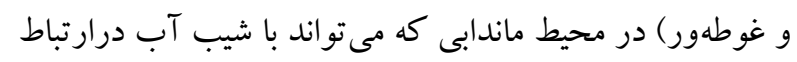

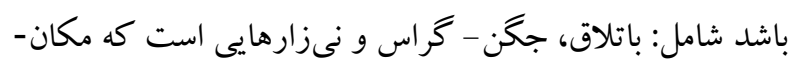
هاى با آب كمعمقتر را اشغال مى كنند Rejmankova et
ارتباط قوى ميان توزيع گونههاى گياهى آبزى و ميزان بى -

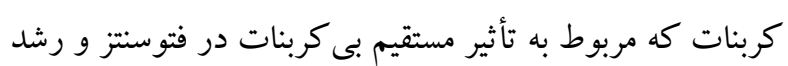

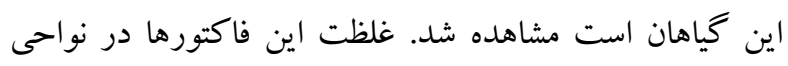
مختلف متفاوت است. اين تغييرات تحت تأثير ميزان بارندگىى،

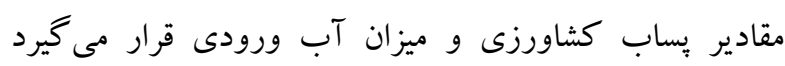

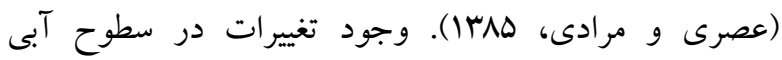

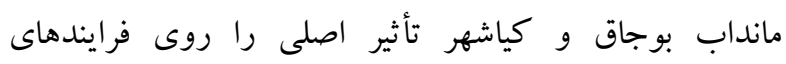




$$
\begin{aligned}
& \text { اقدامات جدى و بيخيرى هاى لازم تا قبل از نابودى اين مانداب- } \\
& \text { هاى بارزش صورت گيرد؛ جراكه گونههاى گياهى در آينده } \\
& \text { درمعرض تغييرات و نابودى قرار خواهند گرفت }
\end{aligned}
$$

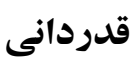

$$
\begin{aligned}
& \text { از يزوهشكدة محيط زيست جهاد دانشكاهى، اداره محيط }
\end{aligned}
$$

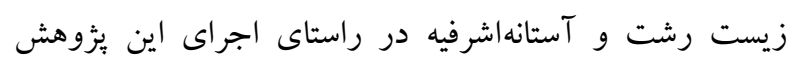

$$
\begin{aligned}
& \text { سباسگز اريم. }
\end{aligned}
$$

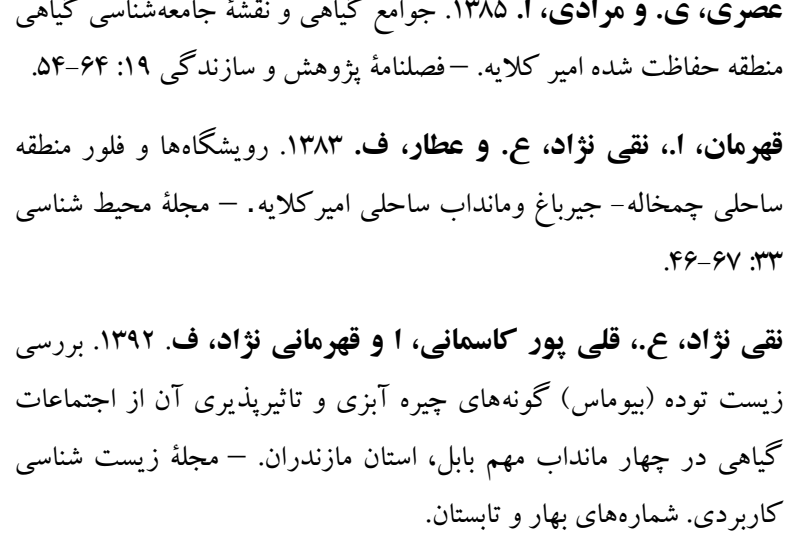

Braun-Blaunquet, J. 1964. Pflanzensoziologie: Grundzuge der Vegetationskunde. - Springer Verlag, Wien-New York.

Burke A. 2001. Classification and ordination of plant communities of the Nauklaft Mountain, Namibia. Journal of Vegetation Science 12:53-60.

Djamali M, Akhani H, Khoshravesh R, Andrieu-Ponel V, Ponel P. and Brewer S. 2011. Application of the global bioclimatic classification to Iran: implications for understanding the modern vegetation and biogeography. - Ecol. Medit. 37: 91-114.

Edward, J. 2000. A Critique for Phytosociology. Journal of Vegetation Science 14: 291-296. (al., 1995، درحالى كه گياهان غوطهور بهطور عمده در

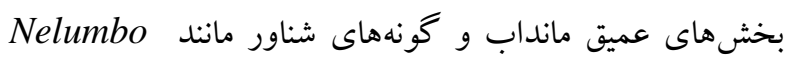

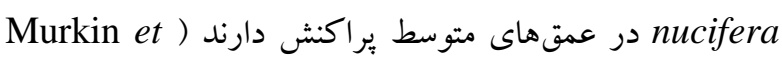

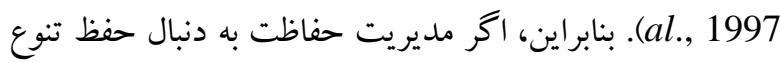

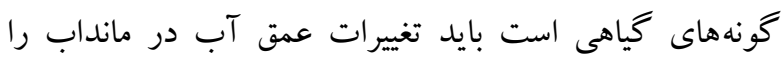
همواره درنظر بخيرد. مانداب بوجاق و كياشهر متأثر از فعاليت-

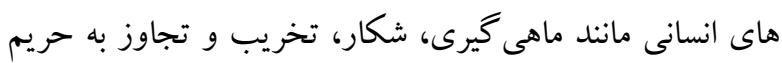
ماندابها است، همجنين بخشهايى از منطقه به فعاليتهاى كشاورزى نيز مبتلا هستند. باتوجه به مشكلات ذكرشده بايد

\section{منابع/ References}

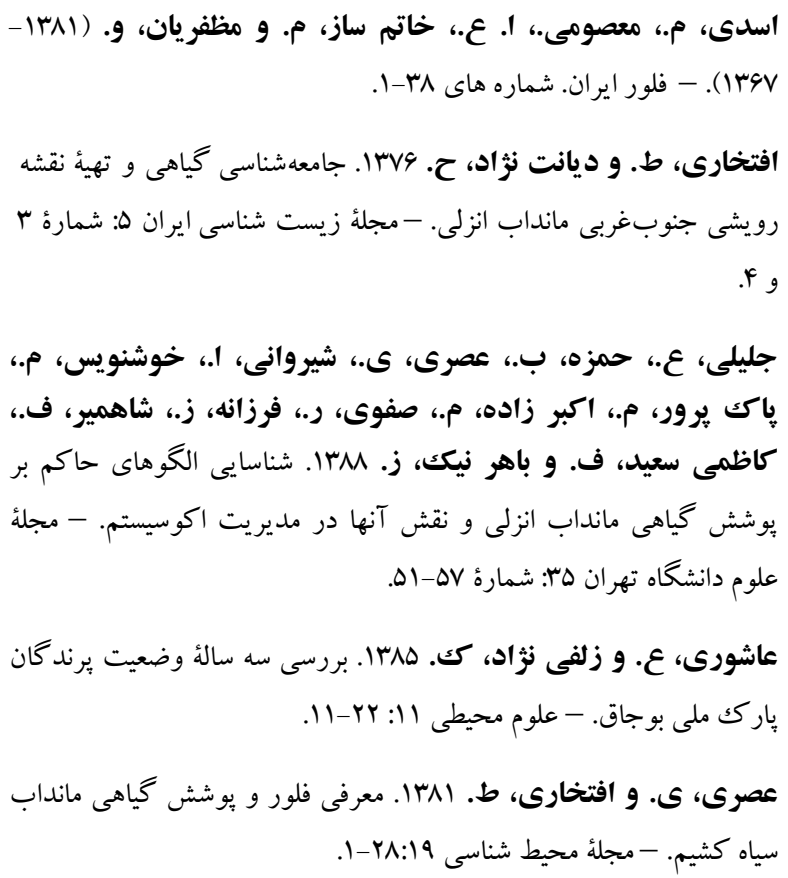

Gerritsen J. and Greening H.S. 1989. Marsh seed banks of the Okefenokee swamp; effects of hydrologic regime and nutrients. - Ecology 70: 750-763.

Hill, M.O. 1979. TWINSPAN: a Fortran program for arranging multivariate data in an ordered two-way table by classification of the individuals and attributes. Cornell ecology programs series. - Cornell University, Ithaca, New York.

Keddy P.A. 2000. Wetland Ecology. Principles and Conservation. - Cambridge University Press, Cambridge.

Kim, K. G., Lee, H. D. and Lee H. 2011. Wetland Restoration to Enhance Biodiversity in Urban Areas-A 
Comparative Analysis, Landscape. - Ecol. Eng. 7: 2732.

Lepš J. and Šmilauer P. 1999. Multivariate analysis of ecological data using CANOCO. - Cambridge, UK: Cambridge University Press.

Murkin H.R., Murkin E.J. and Ball J.P.1997: Avian habitat selection and prairie wetland dynamics: A 10year experiment. - Ecological Applications 7: 11441159.

Murphy, K.J., Dickinson, G., Thomaz, S.M., Bini, L.M., Dick, K., Greaves, K., Kennedy, M.P, Livingstone, S., McFerran, H., Milne, J.M., Oldroyd, J. and Wingfield, R.A. 2003. Aquatic plant communities and predictors of diversity in a subtropical river floodplain: the upper Rio Parana, Brazil. - Aquatic Botany 77: 257-276.

Naqinezhad, A. and Khoshravan, H. 2010. Plant biodiversity of international Ramsar wetlands along the coastline of southern Caspian sea towards a diverse and sustainable situation. - The International Conference on "Biodiversity of the Aquatic Environment "Towards a diverse and sustainable world". Lattakia, Syria.

Naqinezhad, A.R., Saeidi Mehrvarz, S., Noroozi, M. and Faridi, M. 2006. Contribution to the vascular and bryophyte flora as well as habitat diversity of the Boujagh National Park, N. - Rostaniha 7: 83-105.

Prior, G.A. and Berthouex, P.M. 1967. A study of salt pollution of soil by highway deicing. In Highway Research Record 193, HRB. - National Research Council, Washington, DC, 8-21 pp.
Raunkiaer, C. 1934. The life forms of plants and statistical plant geography. Oxford. - Charendon Press.

Rechinger K.H. 1963-1998. Flora Iranica, Vol. 1-173.

Rejmankova E., Pope K.O., Pohl M.D. and Reybenayas J.M. 1995. Fresch-water wetland plantcommunities of Northern Belizeimplication for paleoecological studies of Maya Wetland agriculture. Biotropica 27: 28-36.

Richardson, C.J. and Vymazal, J. 2001. Sampling macrophytes in wetlands. pp: 297-337. In R.B. Radar, D.P. Batzer, and S.A. Wissinger (eds.) Bioassessment and Management of North American Freshwater Wetlands. John Wiley \& Sons, Inc., New York, NY, USA.

Roleček, J., Tichý, L., Zelený, D. and Chytrý, M. 2009. Modified TWINSPAN classification in which the hierarchy respects cluster heterogeneity. - J. Veg. Sci. 20: 596-602.

Sabeti, H. 1969. Les etudes boiclimatique de lran. Publication de Universitede Teheran, No. 1231, 266 pp.

Spence, D.H.N. 1967. Factors controlling the distribution of freshwater macrophytes, with particular reference to the lochs of Scotland. - J. Ecol. 55: 147170.

Tichý L. 2002. JUICE, software for vegetation classification. J. Veg. Sci. 13: 451-453.

Tsuyuzaki S., Urano S. and Tujii T. (1990) Vegetation of alpine marshland and its neighboring areas, northern part of Sichuan Province, China. - Vegetation 88: 7986.

Maghsoudi, M., Saeidi Mehrvarz, S., Naqinezhad, A.R. and Ravanbakhsh, M. 2015. The study of factors affecting the vegetation in aquatic and wet habitats of Boujagh National Park, Kiashahr, Guilan Province, Iran. - Nova Biologica Reperta 2: 176-185.

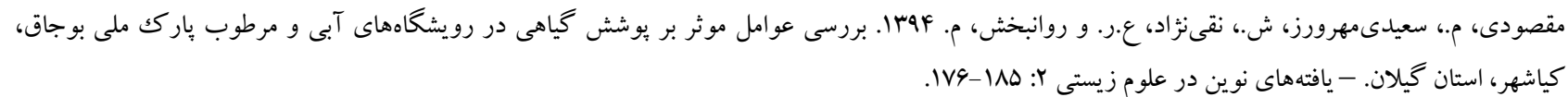


